\title{
Morphological and anatomical aspects of birdsfoot trefoil and big trefoil
}

\author{
Rita Poles Maroso1, Cerci Maria Carneiro², Simone Meredith Scheffer-Basso ${ }^{2,3}$, \\ Daniela Favero ${ }^{1}$
}

\author{
1 Curso de Pós-Graduação em Agronomia - Universidade de Passo Fundo. \\ 2 Universidade de Passo Fundo. \\ ${ }^{3}$ Bolsista de Produtividade CNPq.
}

\begin{abstract}
This study was carried out with the objective of describing the aerial and underground organs of birdsfoot trefoil [Lotus corniculatus (São Gabriel and ARS-2620 cultivars)] and big trefoil [Lotus uliginosus (Maku cultivar)]. The plants were cultivated in pots and harvested at 150 and 210 days after sowing. Stems, leaves and roots were prepared in according to conventional anatomical techniques. The anatomical structures of $L$. corniculatus and L. uliginosus differed in terms of pith cell integrity, starch content in the parenchyma root cell and underground stem cortex. The leaves were amphistomatic, with phenolic idioblasts, small vascular bundles and few conducting elements. The underground system was diffuse, with adventitious shoots that grew in two directions, had no cataphylls, emerged from the ground, and gave rise to aerial stems. The morphological characteristics of the shoot system of both species matched the recent descriptions of soboles.
\end{abstract}

Key Words: Lotus corniculatus, Lotus uliginosus, rhizome, sobole

\section{Aspectos morfológicos e anatômicos de cornichão-comum e cornichão- dos-banhados}

RESUMO - Este trabalho foi realizado para comparar e descrever anatomicamente os órgãos aéreos e subterrâneos de cornichão-comum [Lotus corniculatus (cv. São Gabriel; cv. ARS-2620)] e cornichão-dos-banhados [Lotus uliginosus (cv. Maku)]. As plantas foram cultivadas em vasos e colhidas aos 150 e 210 dias após semeadura. Amostras de caules, folhas e raízes foram preparadas de acordo com as técnicas convencionais de anatomia. As estruturas anatômicas das espécies L. corniculatus e L. uliginosus diferem quanto à integridade das células da medula das hastes, à quantidade aparente de amido nas células do parênquima das raízes e quanto ao tamanho da região cortical dos caules subterrâneos. As folhas são anfiestomáticas, possuem idioblastos fenólicos e feixes condutores de pequeno tamanho e com poucos elementos de condução. O sistema subterrâneo é difuso. Os caules têm origem adventícia, crescimento bipolar, não apresentam catáfilos e, ao emergirem do solo, originam ramos aéreos. As características morfológicas do sistema caulinar subterrâneo das duas espécies estão de acordo com a descrição recente aplicada ao sóbole.

Palavras-chave: Lotus corniculatus, Lotus uliginosus, rizoma, sóbole

\section{Introduction}

Birdsfoot trefoil (Lotus corniculatus L.), one of the forage legume crops introduced and adapted to southern Brazil, has a good yield and tolerates acid and low-fertility soils better than other trefoils (Trifolium spp.). However, its susceptibility to pests, diseases and damage by continuous grazing is a limiting factor. But, as it is tolerant to acid soils, does not cause bloat, has multiple uses and excellent nutritive value, breeding studies have focused on cultivars with a prostrate growth habit and strong underground system, which allow for higher persistence (Paim \& Riboldi, 1991). These characteristics are found in big trefoil (L. uliginosus Schkuhr), which has underground stems, formerly known as rhizomes (Wedderburn \& Gwynne, 1981). Underground stems are highly desirable in forage plants because their buds are protected from herbivory and, therefore, they have a greater shoot regrowth potential and can reproduce by fragmentation.

An advance in birdsfoot trefoil was its breeding with rhizomatous germplasm collected in Morocco, which gave rise to the ARS-2620 cultivar in the United States. Li \& Beuselinck (1996) described that the underground stems of the Moroccan germplasm were very similar to the aerial stems, but originated from the axillary buds in the underground portions of the stems; at ground level, they 
had adventitious roots coming from the broadest portion of the nodes, where scale leaves were found. After some horizontal and underground growth, they emerged from the ground and gave rise to aerial stems.

In Brazil, the first report on underground stems in birdsfoot trefoil populations was made by Soster et al. (2004) and the nature of their stems was confirmed by Maroso et al. (2004) after anatomic studies. That study, however, did not analyze the São Gabriel cultivar and, because of its importance in southern Brazil and Uruguay, where it is used for overseeding in natural pastures, analyses including this cultivar are fundamental.

According to criteria established by Appezzato-daGlória (2003), stems with the characteristics described by Li \& Beuselinck (1996), except for axillary scale leaves, are soboliferous, rather than rhizomatous, and make up a diffuse underground system. Therefore, misleading terminology has been created, even in a recent publication of index terms for Lotus spp. by the Brazilian Cultivar Protection Service (2008), where the term "rhizome" is still used.

This study was conducted to describe the underground system of Lotus spp. and the anatomy of its leaves and aerial stems.

\section{Material and Methods}

Two cultivars of birdsfoot trefoil (São Gabriel, Brazil and ARS-2620, USA) and a big trefoil cultivar (Maku, New Zealand) were planted in pots in a semi-protected environment from May to December 2004. Details on the cultivation, dry matter production, and regrowth were published by Maroso \& Scheffer-Basso (2007). The material for the anatomic examinations was collected at 150 and 210 days after seeding, when the plants were in their vegetative state. Stems and fully expanded leaves were collected from the internode region and the middle third of the central leaflet. The median portions of the underground organs (primary roots and stems) were removed. After collection, specimens were rinsed under running water, and small portions were sectioned and fixed in FAA $70(5 \mathrm{~mL} 40 \%$ formalin, $90 \mathrm{ml} \mathrm{70 \%} \mathrm{ethyl} \mathrm{alcohol,} \mathrm{and} 5 \mathrm{ml}$ glacial acetic acid) for 48 hours. After that, specimens were rinsed under running water and stored in $70 \%$ alcohol (Johansen, 1940).

Slides were mounted after serial dehydration in ascending ethyl alcohol, alcohol-xylene $3: 1,1: 1,1: 3$ and pure xylene, followed by paraffin infiltration and embedding (Sass, 1951). A rotary microtome was used to obtain single or serial 9-micrometer-thick cross-sectional slices. Water at $40^{\circ} \mathrm{C}$ was used to spread the sections, and albumin was used for slide fixation. Basic fuchsine and Astra blue dyes diluted at $0.5 \%$ in $50 \%$ ethyl alcohol were used for staining (Roeser, 1962). After slide preparation and staining, Permount, a synthetic resin, was used as described by Sass (1951). The slides were examined under light microscopy using a Zeiss microscope and a Sony image capture device. Stereoscopic microscopy and digital photography were used for the external examination of underground stems.

\section{Results and Discussion}

The three cultivars had underground stems derived from the adventitious buds of the crown; these stems were seen earlier in cv. Maku, also in terms of root establishment, as observed in plants at 120 days of growth. These stems were achlorophyllous when still underground, had no marked nodes or internodes and no cataphylls (Figure 1). In their description of this cultivar, Li \& Beuselinck (1996) also found underground stems with these characteristics, but mentioned the presence of scale leaves in the nodes. The scales described by those authors may have been, in fact, primordial leaf stipules (Figure 1A) because their size was similar to that of leaflets. Kallenbach et al. (1996) described the birdsfoot trefoil rhizomes collected in Morocco as lateral underground stems that originated at the axillary buds on basal portions of aerial stems; after a period of horizontal growth, the apex of the rhizome became erect, emerged from the ground, and formed a new aerial stem with leaves.

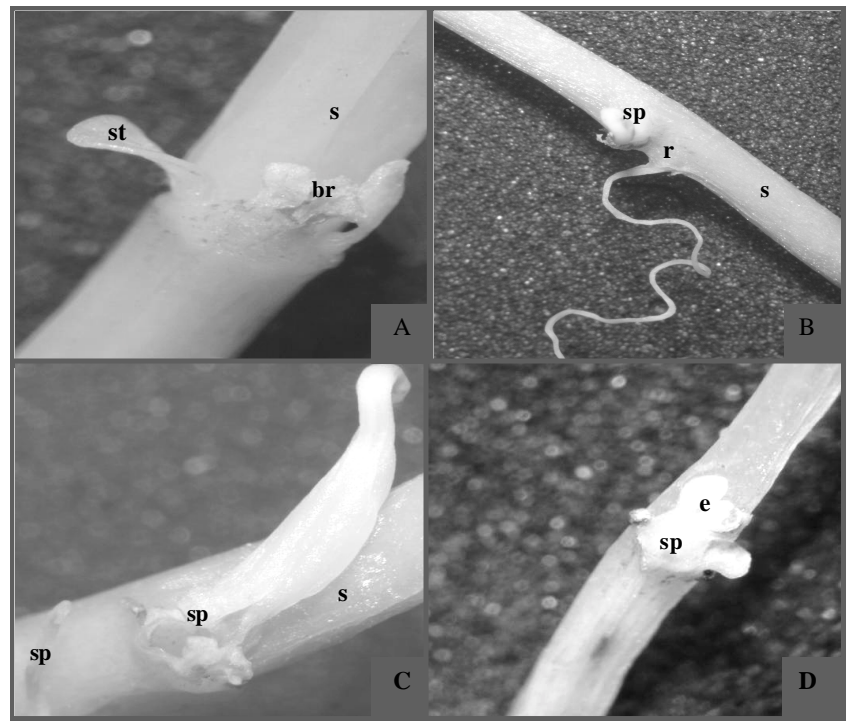

Figure 1 - View of Lotus spp. soboliferous stems at 210 days of growth. 20x magnifications. $\mathrm{A}=\mathrm{cv} . \mathrm{Maku} ; \mathrm{B}=$ rooted cv. Maku; C = cv. ARS-2620; D = cv. S. Gabriel; $\mathrm{sp}=$ sprout $; \mathrm{st}=$ stipules; $\mathrm{r}=\operatorname{root} ; \mathrm{s}=$ sobole. 
In our study, underground stems, after a period of subterranean plagiotropic growth, also emerged from the ground, became chlorophyllous and grew similarly to aerial stems. Such findings were also reported by Beuselinck et al. (2005), who found it difficult to distinguish rhizomes with chlorophyllous apices from the stems originated in the crown. Soster et al. (2004) found underground stems in selected populations of the cvs. São Gabriel and ARS-2620.

No characteristics compatible with rhizomatous stems, such as marked nodes and internodes, cataphylls, and particularly, plumule emergence, were found; only leaves and flower scapes originated in the nodes, which are characteristics of a single-stem system (Appezzato-daGlória, 2003). Thus, the rhizomes described for birdsfoot trefoil and big trefoil (Armstrong, 1974; Wedderburn \& Gwynne, 1981; Li \& Beuselinck, 1996) are probably soboles that had been called rhizomes earlier because up-to-date classifications of underground systems were only issued in 2003 (Appezzato-da-Glória, 2003).

According to Li \& Beuselinck (1996), the term "rhizome" has been widely used to name several parts of a plant, and its meaning is ambiguous. These authors used this term to describe the lateral underground stem of Lotus sp., whereas Bell \& Tomlinson (1980) defined rhizome as a vegetative stem that grows along or inside the substrate by means of axial elongation. This definition, which may also apply to stolons, tubers and corms, is evidence of the generalization of this term and contributes to the incorrect classification of plant structures.

Anatomically, soboles have a stem structure with the pith and the endarch position of protoxylem elements (Figure 2D-E-F). The ARS-2620 and S. Gabriel cultivars have a single-layer epidermis and thin cuticle. The cortex is made up of 5 to 7 layers of small cells and few intercellular spaces. The cortex of cv. Maku has about 10 layers of large cells and larger intercellular spaces than those found in other cultivars (Figure 2F). These characteristics may be associated with the morphology of its sobole, and are evidence of its adaptation to poorly drained soils (Armstrong, 1974). A small amount of starch, as well as other phenolic compounds, probably tannins, was found inside these cells. However, these findings should be confirmed because no histochemical analyses were performed.

The sobole conducting system in both species is made up of 11 vascular bundles and randomly distributed xylem components. The external portion of the phloem had fiber caps, more markedly in ARS-2620 and the S. Gabriel cultivars. These findings confirm those reported by

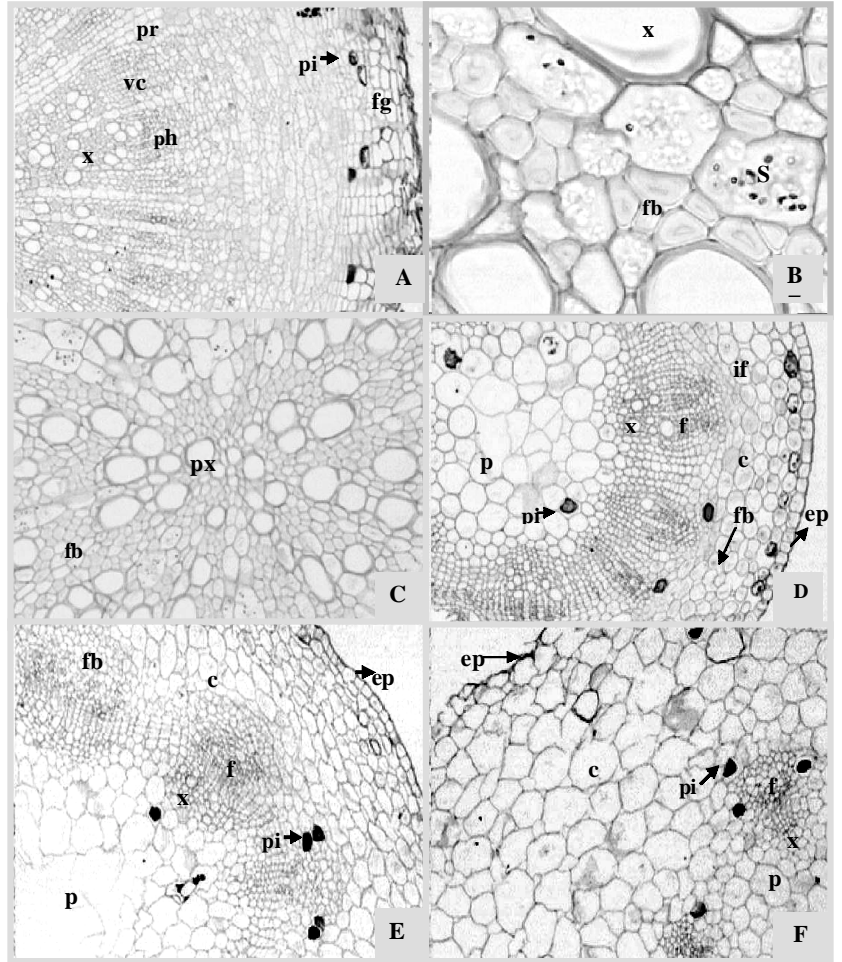

Figure 2 - Cross-sections of underground organs of Lotus cultivars at 210 days of growth. Roots: $A=c v$. S. Gabriel; B = cv. ARS-2620; C = cv. S. Gabriel. Soboles: $D=c v$. ARS-2620; E = cv. S. Gabriel; $F=c v$. Maku; $\mathrm{S}=$ starch; vc = vascular cambium; $\mathrm{c}=$ cortex; $\mathrm{ep}=$ epidermis $; \mathrm{ph}=$ phloem $; \mathrm{fb}=$ fiber; $\mathrm{pi}=$ phenolic idioblasts; $\mathrm{p}=$ pith; $\mathrm{pr}=$ phloem rays; $\mathrm{x}=\mathrm{xylem}$. (Bar: A, B, C, D = $100 \mu \mathrm{m} ; \mathrm{E}=50 \mu \mathrm{m} ; \mathrm{F}=200 \mu \mathrm{m}$ ).

Maroso et al. (2004) in their study of Lotus spp. populations and cultivars, but are different from those described by Li \& Beuselinck (1996), who found 6 to 7 vascular bundles in these stems.

The phloem was formed by cortically oriented rays and thick-walled cells, apparently lignified. It extended from the central portion of the root and is found between the parenchyma cells of the rays (Figure 2A-B). The formation of the vascular cambium and phellogen was at its initial phase, which was expected because of the vegetative state of the cultivars. Starch grains were seen in the central parenchyma cells of the roots, at greater rates in the São Gabriel and ARS-2620 cultivars than in the cv. Maku (Figure 2B). The three poles of exarch protoxylem were characteristics of exarch root formation (Figure 2C).

The aerial stems had a single-layer epidermis, thin walls, the external periclinal area was covered by a thin cuticle and there were few stomata (Figure 3A-B). The cortex was made up of around eight cell layers, reduced 
intercellular spaces, and a central cylinder formed by 9 to 11 vascular bundles. The plants examined at 210 days showed signs of initial formation of the vascular cambium. The fiber caps found in the phloem next to the cortex were probably associated with the accumulation of supporting tissues, which may have explained why its nutritive value was lower than that of the leaves. López et al. (1966) found 58 to $68 \%$ in vitro digestibility in the stems and 65 to $81 \%$ in the leaves of birdsfoot trefoil.

In the cv. Maku, the central cylinder had substantially lignified xylem conducting elements and thicker walls (Figure 3B). The three cultivars had pronounced pith, but the S. Gabriel and ARS-2620 cultivars had more whole cells (Figure 3; 1). In the cv. Maku, the pith was hollow and there were fewer whole cells (Figure 3B).

In parenchyma cells, ergastic substance deposition was usually found close to the vascular bundles and at greater rates in the cv. ARS-2620. These anatomical

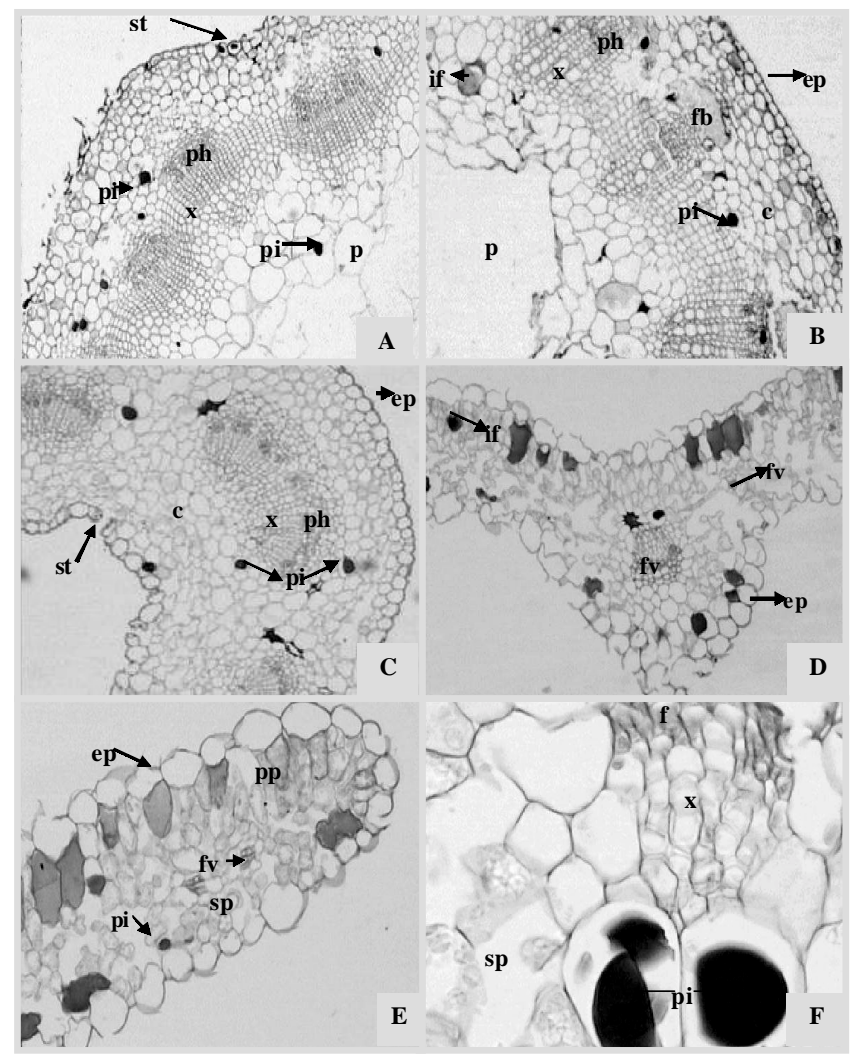

Figure 3 - Cross-sections of aerial organs of Lotus cultivars at 210 days of growth. Stems: $A=c v$. S. Gabriel; $B=c v$. Maku. Petiole: $\mathrm{C}=\mathrm{cv}$. Maku. Leaves: $\mathrm{D}=\mathrm{cv}$. $\mathrm{S}$. Gabriel; $\mathrm{E}=\mathrm{cv} . \mathrm{S}$. Gabriel; $\mathrm{F}=\mathrm{cv}$. ARS-2620. $\mathrm{c}=$ cortex ; ep = epidermis; $\mathrm{st}=$ stoma; $\mathrm{ph}=$ phloem; $\mathrm{fb}=$ fiber; $\mathrm{pi}=$ phenolic idioblasts; $\mathrm{p}=$ pith; $\mathrm{sp}=$ spongy parenchyma; $\mathrm{pp}=$ palisade parenchyma; $\mathrm{x}=\mathrm{xylem}$. (Bar: A, B $C, D=200 \mu \mathrm{m} ; \mathrm{E}=100 \mu \mathrm{m} ; \mathrm{F}=50 \mu \mathrm{m}$ ). structural characteristics of birdsfoot trefoil stems are in agreement with those described by Li \& Beuselinck (1996), who suggested that these substances were tannins (Figure 3A-B). According to Brandes \& Freitas (1992), tannins play a fundamental role in preventing bloat and protect against protein degradation in the rumen.

The presence of ergastic substances in the vascular region may be related to the presence of storage cells and serve as protection of the protoplast against desiccation, putrefaction and pathogens (Esau, 1985). Cell composition, the presence of substances that favor the use of proteins by ruminants, and the proportions of tissue in the cultivars analyzed, particularly the high percentage of parenchyma cells, suggested that this forage crop is of good quality.

The cross-section of the petiole showed a winged pattern, single-layer epidermis, thin cuticle, and stomata. There were three vascular bundles, one in each wing and both smaller than the one in the central portion (Figure 3C). In the vascular bundles, there was less xylem than phloem. According to Esau (1974), there are many anatomic similarities between the petiole base and plant stems, and these features are different only in the portion closest to the leaf. Petiole tissue and stem digestibility is similar, and both are less degradable than leaves (Nelson \& Moser, 1994). This may be explained by the greater proportions of vascular bundles and the greater deposition of cellulose, hemicellulose and lignin in the stems and petioles than in the leaf blades. Although few studies have assessed petioles, their tissues and cell composition suggest that they are the leaf component with the lowest degradability.

Leaves were dorsiventral and amphistomatic. The adaxial and abaxial surfaces were covered with a singlelayer epidermis and had thin cell walls and cuticle (Figure 3D-E). Mesophyll, the tissue found in the largest amount, was made up of the palisade parenchyma with two cell strata on the adaxial side and underlying spongy parenchyma. The palisade parenchyma was continuous and extended to the leaf edge without interruption at the midrib (Figure 3D). The conducting bundles were small, had few conducting elements and only three xylem elements. The area of the midrib had more parenchyma cells than the bundles (Figure 3E). These characteristics favor degradability and the use of leaf tissues. Similarities to the leaf structure of alfalfa (Medicago sativa $\mathrm{L}$.) were described by Esay (1985), who found that the palisade parenchyma was made up of two cell layers.

The samples analyzed had phenolic idioblasts in the mesophyll cells (Figure 3F), which confirmed the findings by Brandes \& Freitas (1992). Data on the leaf anatomy of 
these species confirmed the findings reported by SchefferBasso et al. (2001), Norton (1981) and Albrecht et al. (1987), who described the high nutritive value of Lotus spp. As the parenchyma is quickly degraded by microorganisms in the rumen (Hanna et al., 1973), the larger amount of this tissue in the leaves than in the stems may contribute to its greater concentration of proteins and better degradation.

\section{Conclusions}

Underground stems of Lotus corniculatus and Lotus uliginosus are adventitious shoots that grow in two directions, have no cataphylls, emerge from the ground, and give rise to aerial stems. These features, according to the current classification of underground systems, characterize them as soboles. L. uliginosus differs from L. corniculatus because it has soboles with a thicker cortex and more intercellular spaces, aerial stems with thicker walls, hollow pith, and fewer whole cells. The leaves of both species are amphistomatic, have phenolic idioblasts, small conducting bundles and few conducting elements.

\section{Literature Cited}

ALBRECHT, K.A.; WEDIN, W.F.; BUXTON, D.R. Cell-wall composition and digestibility of alfalfa stems and leaves. Crop Science, v.27, p.735-741, 1987.

APPEZZATO-DA-GLÓRIA, B. Morfologia de sistemas subterrâneos: história e evolução do conhecimento no Brasil. 1.ed. Ribeirão Preto: Editora e Arte, 2003.

ARMSTRONG, B.S.C. Grasslands Maku' tetraploid Lotus (Lotus pedunculatus Cav.). New Zealand Journal of Experimental Agriculture, n.2, p.333-336, 1974.

BELL, A.D.; TOMLINSON, P.B. Adaptative architecture in rhizomatous plants. Botanical Journal of the Linnean Society, v. 80, p.125-160, 1980.

BEUSELINCK, P.R.; BRUMMER, E.C.; VIANDS, D.K. et al. Genotype and environment affect rhizome growth of birdsfoot trefoil. Crop Science, v.45, p.1736-1740, 2005.

BRANDES, D.; FREITAS, E.A.G. Taninos condensados: uma ferramenta para melhorar o desempenho de ruminante. Agropecuária Catarinense, v.5, n.3, p.44-48, 1992.

ESAU, K. Anatomia das plantas com sementes. 14.ed. São Paulo: Edgard Blücher, 1974.

ESAU, K. Anatomia vegetal. 3.ed. Barcelona: Omega S.A, 1985. $782 \mathrm{p}$.
HANNA, W.W.; MONSON, W.G.; BURTON, G.W. Histological examination of fresh forage leaves after in vitro digestion. Crop Science, v.13, p.98-102, 1973.

JOHANSEN, D.A. Plant microtechnique. New York: McGraw-Hill, 1940. 523p

KALLENBACH, R.L.; McGRAW, R.L.; BEUSELINCK, P.R. Soil pH effects on growth and mineral concentration of birdsfoot trefoil. Canadian Journal Plant Science, v.76, p.263-267, 1996.

LI, B.; BEUSELINCK, P.R. Rhizomatous Lotus corniculatus L. II. Morphology and anatomy of rhizomes. Crop Science, v.36, n.2, p.407-411, 1996.

LÓPEZ, J.; PRESTES, P.J.Q.; MAGAlHÃes, E. A curva de crescimento e a composição em carboidratos solúveis, estruturais, lignina e proteína, e a digestibilidade em cornichão. In: CONGRESSO INTERNACIONAL DE PASTAGENS, 9., 1966, São Paulo. Anais... São Paulo: Alarico, 1966. p.851-857.

MAROSO, R.P.; CARNEIRO, C.M.; BORDIGNON, M.V. et al. Variabilidade morfológica do sistema subterrâneo de Lotus corniculatus L. Agrociência, v.8, n.2, p.73-78. 2004.

MAROSO, R.P.; SCHEFFER-BASSO, S.M. Desenvolvimento morfológico de Lotus spp. de diferentes hábitos de crescimento. Revista Brasileira de Zootecnia, v.36, n.6, p.1961-1968. 2007.

MAROSO, R.P.; SCHEFFER-BASSO, S.M.; CARNEIRO, C.M. Rebrota de Lotus spp. de diferentes hábitos de crescimento. Revista Brasileira de Zootecnia, v.36, n.5, p.1524-1531, 2007.

NELSON, C.J.; MOSER, L.E. Plant factors affecting forage quality. In: FAHEY, J.C. (Ed.) Forage quality, evaluation, and utilization. Madison: American Society of Agronomy, 1994. p.115-154.

NORTON, B.W. Differences between species in forage quality. In: HACKER, J.B. (Ed.) Nutritional limits to animal production from pastures. Queensland: University of Queensland, 1981. p.98-110.

PAIM, N.R.; RIBOLDI, J. Comparação entre espécies e cultivares do gênero Lotus. Pesquisa Agropecuária Brasileira, v.26, p.1699-1701, 1991.

ROESER, K.R. Die nadel der schwarzkiefer-massen produkt and kunstwerk der natur. Mikrokosmos, v.61, p.33-36, 1962.

SASS, J.E. Botanical microtechnique. Iowa: The Iowa State College Press, 1951. 228p.

SCHEFFER-BASSO, S.M.; JACQUES, A.V.A.; DALL'AGNOL, M. et al. Disponibilidade e valor nutritivo de forragem de leguminosas nativas (Adesmia DC.) e exóticas (Lotus L.). Revista Brasileira de Zootecnia, v.30, n.3, p.975-982, 2001.

SERVIÇO NACIONAL DE PROTEÇÃO DE CULTIVARES. Instruções para execução dos ensaios de distinguibilidade, homogeneidade e estabilidade de cultivares de Lotus spp. Diário Oficial da União, n.43, 2008.

SOSTER, M.T.B; SCHEFFER-BASSO, S.M.; DALL'AGNOL, M. Caracterização morfofisiológica de genótipos de cornichão (Lotus corniculatus L.). Revista Brasileira de Zootecnia, v.33, n.6, p.1654-1661, 2004.

WEDDERBURN, M.E.; GWYNNE, D.C. Seasonality of rhizome and shoot production and fixation in Lotus uliginosus under upland conditions in South-West Scotland. Annals of Botany, v. 48, n.1, p.8-13, 1981 . 